\title{
Hegesztőrobotok telepítésének biztonsági kérdései
}

\section{Safety Issues Concerning Installation of Welding Robots}

\author{
Bekő Bálint, ${ }^{1}$ Gáti József,2 Némethy Krisztina ${ }^{3}$ \\ ${ }^{1}$ Óbudai Egyetem, Bánki Donát Gépész és Biztonságtechnikai Mérnöki Kar, Budapest, Magyarország, \\ bekob.main@gmail.com \\ 2 Óbudai Egyetem, Bánki Donát Gépész és Biztonságtechnikai Mérnöki Kar, Anyag-és Gyártástudományi \\ Intézet Budapest, Magyarország, gati@uni-obuda.hu \\ ${ }^{3}$ IBS, Budapest, Magyarország, knemethy@ibs-b.hu
}

\begin{abstract}
The aim of this research is to summarize the safety measures related to the application of welding robots, as well as to apply them in the ÓE-Cloos Robot Welding Laboratory of Bánki Faculty at Óbuda University. This article describes the safety requirements for welding robot systems, the requirements for commissioning and safe operation. The concluding part of the dissertation presents the preparation and implementation of the installation of a new robot cell in the laboratory.

Keywords: welding, welding robot, welding robot operation, welding robot installation.

\section{Összefoglalás}

A tudományos munka célja a hegesztőrobotok alkalmazásához köthető biztonsági intézkedések összegzése, valamint mindezek alkalmazása az Óbudai Egyetem Bánki Karának ÓE-Cloos robothegesztő laboratóriumában. A cikk bemutatja a hegesztő robotrendszerekkel szemben támasztott biztonsági követelményeket, az üzembe helyezés, valamint a biztonságos üzemeltetés követelményeit. A dolgozat befejező része a laboratóriumba új robotcella telepítésének előkészítését és megvalósítását mutatja be.
\end{abstract}

Kulcsszavak: hegesztés, hegesztörobot, robot-üzemeltetés, telepítés.

\section{A hegesztőrobotok alkalmazása}

Az összes robotalkalmazási terület között a hegesztés igen jelentős arányt képvisel: 2010-ben a világon üzemelő több, mint egymillió ipari robot 30\%-a hegesztőrobot, a 2010-es robotértékesítéseknek pedig 26\%-a volt hegesztőrobot. A hegesztőrobot-alkalmazáson belül a két meghatározó területet az ellenállás-ponthegesztés és a huzalelektródás, védőgázos ívhegesztés jelenti. A két eljárás nagyjából fele-fele arányban oszlik meg, az utóbbi években az arány kismértékben az ívhegesztés felé helyeződik át [1]. Napjainkban egyre több vállalatnak nyílik lehetősége hegesztőrobot alkalmazására. Beszerzésük legfőbb indokát a tömeggyártásban kell keresnünk: a termékeknek az egyre növekvő igényeknek kell megfelelniük, mind darabszámot, mind a minőséget illetően.
A tömeggyártást gazdaságosabbá teszi a hegesztőrobot alkalmazása. A robot megfelelő alkalmazásához elengedhetetlen, hogy a munkafolyamatra könnyen lehessen programozni: pontról pontra kell betanítani azokat a kitüntetett pontokat, melyeken keresztül kell majd a robotnak az egyes pontokban megadott - pontvezérlésű vagy valamilyen pályavezérlésű - pályán haladni.

A robotprogramozás két nagy csoportra osztható. -Az online programozás során magát a robotot programozzák, ami megköveteli a robot jelenlétét: a robotot, vagy annak modelljét mozgatva tanítják be a hegesztőfej által bejárandó útvonalat.

-Az offline programozás alatt a gyártási folyamatot nem kell megszakítani, a programozás számítógéppel történik, ily módon azt a többlet gyártási időt lehet megtakarítani, amit a betanítás jelentene. 


\section{A hegesztőrobotok telepítésének kritériumai}

Általános rendelkezésként a gépekkel összefüggő követelményeket „Az Európai Parlament és a Tanács 2006/42/EK irányelve a gépekről” fogalmazza meg [2]. A gépi berendezések, így a hegesztőrobotok telepítésére, üzemeltetésére nemzetközi előírások, szabványok és hazai rendeletek vonatkoznak, melyeket a munkavédelmi üzembe helyezés kritériumainál összesítettünk.

\subsection{A robot elhelyezése}

A megfelelő robot kiválasztását követően a specifikációk ismeretében szükséges felmérni a robot telepítésének lehetséges helyét. A telepített hegesztőmunkahely alapterülete legalább $4 \mathrm{~m}^{2}$ az előírás szerint [3]. A telepítési hely kiválasztását nagymértékben befolyásolja a robot mozgástartománya, a munkaterülete. Napjaink korszerü programozási módszerei lehetővé teszik, hogy a robotok alapkonfigurációjának tartalmát korlátozzák, akár különböző komponensek letiltásával, így a munkaterület is testre szabható szoftveres biztonsági alkalmazással. A robot miatt közvetlen veszélyben lévő terület nagyságát a gyári katalógusok megadják, a gépkönyvek tartalmazzák.

\subsection{Helyiség}

Miután a kiválasztott helyszín megfelel a területi alapkövetelménynek, további szempontokat kell megvizsgálnunk, nem csak munka- és munkaegészségügyi, hanem ergonómiai elvek alapján is. A helyiség megvilágításának az adott munkához szükségszerűen meg kell felelnie, de minden esetben meg kell haladja a 300 luxot. Ez az alsó határa a megfelelő megvilágításnak, mely még nem károsítja az emberi szem egészségét. Amennyiben természetes megvilágítása is van a helyiségnek, úgy kötelező az ablaküveget védőfóliával kell ellátni [4]. Megvizsgálandó a födém teherbíró képessége is, ugyanis a robot és a vele együtt telepítendő perifériák, kiszolgáló egységek, a munkadarabok tömege, valamint az azokat kiszolgálókkal együttesen jelentős terhelést képviselnek. Amennyiben kielégítő állapotú a födém, a következő elem a burkolat vizsgálata, melynek csúszásmentes, nem éghető anyagból kell készülnie; egyenletes padozat kialakítása az előírás. Amennyiben a robot üzemeltetésével együtt járó zajhatás a munkavégzés közben nem haladja meg a $85 \mathrm{~dB}$ értéket, úgy nem szükséges külön hangszigetelést biztosítani, viszont minden más esetben gondoskodni kell róla.

\subsection{Elhatárolás}

A telepítendő robotrendszer egyes elemeinek specifikációja ismeretében kell meghatározni a mechanikai biztonság összetevőit. Ezek egyik meghatározó eleme a robotrendszer működési határainak meghatározása, amit nagymértékben befolyásol a rendszer egyes elemeinek elrendezése, a robot mozgástartománya, a munkaterülete. A hegesztőrobotok, robotállomások telepítése során megfelelő elkerítésről kell gondoskodni, hogy a berendezést üzemeltető, illetve bármely személy véletlen vagy szándékosan a robot munkaterébe kerülve, ne szenvedjen sérülést. Ennek egyik lehetséges módja a mechanikai biztonsági elkerítés kialakítása. A kerítés lehet rácsos vagy telifalas kivitelü, mely kialakítás egyben biztosíthatja az ívfény elleni védelmet. A térelhatároló elem, illetve a padló között az előírások szerint $150 \mathrm{~mm}$-es légrést szükséges biztosítani [3]. A hegesztéssel óhatatlanul együtt járó fröcskölés veszélyezteti a robot perifériákat és a hegesztőkészüléket is. Emellett a hegesztés során keletkezett salak, illetve izzó fémrészecske a munkaterületen tüzet okozhat. Elengedhetetlen a munkaterületen használt, a munkaterülethez tartozó eszközök biztonságos elhelyezése, a robot energiaellátását biztosító kábelek, vezetékek megfelelő elhatárolása, takarása. Érintésvédelmi vizsgálat elvégzése is szükséges, melyet csak szakember végezhet.

\section{4. Ívfény elleni védelem}

Az elhatárolás című alfejezetben már szóba került az ívfény elleni védelem szükségessége, valamint annak fontossága. A hegesztéskor keletkező ívfény energiája három összetevőből áll: ultraibolya sugárzás, látható fény, valamint az infravörös sugárzás. Az ibolyántúli sugárzás a szem szaruhártyájának gyulladását okozhatja. A látható sugárzás hőhatása révén károsítja a retinát, és fotokémiai folyamatok elindításával látáskárosodást okozhat. A veszélyt fokozza, hogy a káros hatás a szemben halmozódik. Az infravörös sugárzás szemet károsító hatása szintén a sugárzó hőhatás következménye. A munkavédelmi eszközök nem megfelelő, vagy használatának hiányában - szürkehályog, szaruállomány-, retina-, illetve szemlencse károsodás, sárgatest sorvadás, részleges vakság, szélső, súlyos esetben a látás teljes elvesztése - fordulhat elő. A hegesztéssel együtt járó fénysugárzás biológiai hatásának megszüntetése, illetve csökkentése érdekében a bőrfelületet takarással, a szemet védőszürő használatával óvni kell. Az alkalmazandó védőszűrő fokozatát 
meghatározza a hegesztési eljárás, az áramerősség, illetve az energiaforrás intenzitása, a hozag-, az alap-, és a segédanyag, valamint a környezeti megvilágítás. Általánosan elfogadott szabály, hogy nagyobb teljesítményü hőforrás, illetve kedvezőtlenebb környezeti megvilágítás esetén erősebb fokozatú szűrőt kell használni. Az ívfény elleni védelmet telilemezelt vagy olyan biztonsági védőrács kialakítása biztosíthatja, amely ívhegesztési célra alkalmas védőfüggönnyel fel van szerelve. A robotállomás kiszolgáló oldalán mobil ívfényvédelem alkalmazható, mely lehet

- pozicionálóberendezésre szerelt fényvédő fal, amely együtt fordul el a kétmunkahelyes pozicionálóberendezéssel, és a kiszolgálási oldalt munkapozícióban elválasztja a belső tértől, ahol a robot hegeszt;

- biztonsági ajtó, amely az ívfény elleni védelmet is szolgálja;

- automata fényvédő függöny, kézzel elhúzható fényvédő függöny [5].

\subsection{Légcsere}

A szellőztetést, a hegesztés során keletkező károsanyag elszívását biztosítani kell az ergonomikus munkavégzéshez. A hegesztőrobotoknál is megfelelő elszívó-, szűrőrendszerek alkalmazásáról kell gondoskodni, melyek kiválasztása függ a hegesztési eljárástól és a robotállomástól. Az elszívó-szürő berendezés lehet központi elszívó-szűrő berendezés, a hegesztőfejre vagy közvetlenül mellé elhelyezett mobil elszívó, vagy a robot fölé szerelt szívóernyő. A szívóernyő elhelyezése, nagysága és kialakítása az egyedi robot vagy az adott üzemben alkalmazott robotrendszer elrendezésétől, felépítésétől függ. Az elszívó indítása és leállítása általában automatikus; kedvező, ha a robotrendszer vezérlésébe integrált [5].

\subsection{Tüzvédelem}

A helyiségben folyó munkához természetesen tűzvédelmi előírások is tartoznak. Ezeket az előírások a mindenkori hatályos jogszabályok és belső szabályzatok tartalmazzák. A kábeleket, ahol lehetséges, kábelcsatornával kell lefedni, mely megakadályozza a kábelek meggyulladását, valamint karbantartás közben, esetleg a szükséges vészleállítást követően az ellenőrző személy vagy dolgozó elesését. Amennyiben a helyiségben védőgázos hegesztést végeznek, úgy különböző gázpalackok is kerülhetnek a munkaállomás közelébe, legyen szó akár argonról vagy szén-dioxidról; a palackokat rögzíteni szükséges.
A gázokon kívül potenciális veszélyforrást jelentenek még a korábban említett izzó fémrészecskék. Ellenük a kábelek kábelcsatornával való lefedésével védekezünk. A biztonság érdekében mindenképp szükséges szén-dioxiddal oltó készüléket a helyszínen készenlétben tartani. A menekülési tervet is ki kell helyezni, az útvonalat kijelölni, a kijáratot megfelelően jelezni, nyitva tartásukról, vagy nyithatóságukról gondoskodni.

\section{A hegesztőrobot üzembe helyezése}

A robot telepítését követően a munka csak úgy kezdődhet meg, hogyha a munkavédelmi üzembe helyezés megtörtént. Az eljárás során a munkavédelmi, tűzvédelmi szakember megvizsgálja, hogy a robot megfelelősége igazolt-e, valamint azt, hogy a korábban kifejtett szempontoknak eleget tett-e a munkáltató. A munkáltatónak kötelező egy működési és üzemi szabályzatot létrehoznia. A hegesztőrobot kezeléséhez szükséges egy hegesztőrobot-programozói jogosítvány megszerzése, ami tanfolyam keretein belül zajlik. Az üzembe helyezési jegyzőkönyvnek tartalmaznia kell

- az üzembe helyezés időpontját;

- a robot gyártási számot;

- a műszaki, biztonsági feltételeket tételesen;

- a hatósági engedélyeket;

- a beruházott eszközzel kapcsolatos összes anya-

gi kötelezettségvállalást (pl. logisztikai díjak);

- a várható élettartamot;

- az átvevő gyár, gyárrészleg nevét, felelősségvál-

laló személyét;

- az átvétel időpontját [6].

A robot programozási-, az alkalmazott a munkadarab pozicionáló szerelési útmutatója tartalmazza a biztonsági utasításokat, a karbantartással kapcsolatos információkat, emellett meghatározza az egyes alkatrészek várható élettartamát, valamint az időszakos csere idejét.

A karbantartást, javítást csak szakirányú képesítéssel rendelkező, valamint erre felhatalmazott személy végezheti a gyártó által kibocsátott használati utasítás alapján [4]. Ettől függetlenül a felhasználótól elvárható, hogy ne legyen teljesen laikus a robotokkal kapcsolatos előírások tekintetében, hiszen a belső képzéseknél vagy fellépő problémák esetén ismernie kell a protokollokat. Az időszakos ellenőrzés során vizsgálni kell,

- a robot felületét, sérülések keresése céljából;

- a villamos kábeleket;

- a védőgázos hegesztés során az ellátó vezetékeket;

- az áramellátó berendezést; 
- a vészleállítót;

- a programozó felület megfelelő működését;

- a munkadarab-befogók, a célberendezések állapotát [4].

A karbantartást vagy javítást követően az üzembe helyező nem vonható felelősségre hiba esetén, ugyanis a karbantartással vagy javítással megbízott személynek hivatalos, dokumentált formában kell nyilatkoznia az általa végzett tevékenységről. A karbantartási jegyzőkönyv hitelessége teljes mértékben a hitelesítő felelőssége.

\subsection{A munkavédelmi üzembe helyezés kritériumai}

Egy hegesztő robotrendszer használatára vonatkozó követelményeket a munkavédelemre vonatkozó törvény előírásaiból, valamint a Hegesztési és Biztonsági Szabályzatból lehet levezetni [7]. A munkavédelmi törvény 18. §. (3) bekezdése szerint: „Munkaeszközt üzembe helyezni, valamint használatba venni csak abban az esetben szabad, ha az egészséget nem veszélyeztető, és biztonságos munkavégzés követelményeit kielégíti, és rendelkezik az adott munkaeszközre, mint termékre vonatkozó, külön jogszabályokban meghatározott EK megfelelőségi nyilatkozattal, illetve megfelelősséget tanúsító egyéb dokumentummal (pl. tanúsítvány).” [7] E tekintetben az Európai Parlament és a Tanács 2006/42/EK irányelve [2] tartalmazza a meghatározó követelményeket, öszszhangban a vonatkozó MSZ EN ISO szabványokkal, melyek a következőek

- MSZ EN ISO 12100:2011 Gépek biztonsága. A kialakítás általános elvei. Kockázatértékelés és kockázatcsökkentés;

-MSZ EN ISO 10218-1:2011 Robotok és robotszerkezetek. Ipari robotok biztonsági követelményei. 1. rész: Robotok;

-MSZ EN ISO 10218-2:2011 Robotok és robotszerkezetek. Ipari robotok biztonsági követelményei. 2. rész: Robotrendszerek és összehangolásuk;

-MSZ EN ISO 13857:2020 Gépek biztonsága. Biztonsági távolságok a veszélyes terek felső és alsó végtagokkal való elérésének megakadályozására/megelőzésére;

- MSZ EN ISO 13850:2016 Gépek biztonsága. Vészleállítás. Tervezési alapelvek.

-Hegesztő robotrendszerek munkavédelmi üzembe helyezése során a megfelelőség értékelése ki kell, hogy terjedjen a hegesztéssel járó veszélyek kockázatának kezelésére is [5]. Ez azt jelenti, hogy a hegesztés során a robotrendszer minimum két, alkalmazás szempontjából elkülönülő egységből épül fel, úgymint

- a hegesztőpisztoly és/vagy a munkadarab öszszehangolt mozgatására szolgáló gépi berendezésből (robot, illetve manipulátor), melynek ki kell elégítenie a gépekről szóló 2006/42/EK irányelvet és az ennek megfelelő harmonizált magyarországi jogszabályt, a 16/2008. (VIII. 30. NFGM rendelet követelményeit;

-ívhegesztő berendezésből, melynek meg kell felelnie a kisfeszültségű villamos termékekre (LVD) és az elektromágneses kompatibilitásra (EMC) vonatkozó direktívának, a vonatkozó harmonizált szabványok követelményeinek, illetve a hegesztő munkaeszközökre vonatkozó követelményeknek, így a Hegesztési Biztonsági Szabályzatnak (HBSZ) [7].

Az ívhegesztő berendezésekre vonatkozó hatályos EU-s irányelvek:

-2014/35/EU - LVD Kisfeszültségü villamos termékek;

-2014/30/EU EMC Elektromágneses zavart okozó berendezés.

A vonatkozó szabványok:

-MSZ EN 60204-1:2006 Gépi berendezések biztonsága. Gépek villamos szerkezetei. 1. rész: Általános követelmények;

-MSZ EN IEC 61000-6-2:2019 Elektromágneses összeférhetőség (EMC). 6-2. rész: Általános szabványok. Az ipari környezet zavartűrése;

-MSZ EN 61000-6-4:2007/A1:2011 Elektromágneses összeférhetőség (EMC). 6-4. rész: Általános szabványok. Az ipari környezetek zavarkibocsátási szabványa;

-MSZ EN IEC 60974-1:2019 Ívhegesztő berendezések. 1. rész: Hegesztő áramforrások;

-MSZ EN 60974-10:2008 Ívhegesztő berendezések. 10. rész: Elektromágneses összeférhetőségi (EMC) követelmények.

Annak érdekében, hogy a hegesztő robotrendszer forgalomba hozható legyen, a gyártónak el kell látnia CE-jelöléssel, mely igazolja, hogy a robotrendszer (az előzőekben jelzett mindkét elkülönült egysége) megfelel a vonatkozó valamennyi előírásnak.

\section{4. Óbudai Egyetem - Cloos robothegesz- tő állomás kialakítása}

\subsection{Előzmények}

2009. október 26-án az Óbudai Egyetem Bánki Donát Gépész és Biztonságtechnikai Mérnöki Kara a Crown International Kft. CLOOS-képviseletével való eredményes együttműködést követő- 
en robothegesztő laboratóriummal gazdagodott. A megfogalmazott cél, a modern ipari eszközök bemutatása az oktatásban, valamint a kutatások elősegítése volt. A Népszínház utcai épületben kialakított és üzemelő robothegesztő állomás müködtetéséhez a Crown International Kft. az elmúlt 10 évben folyamatosan rendelkezésre bocsájtott új, komplett robothegesztő cellát és gondoskodott azok üzemeltetéséről.

\section{2. Új robotrendszer telepítése}

2019-ben a korábbi korszerüsítési folyamat folytatásaként a CROWN International Kft. új hegesztő robotrendszer adományozását irányozta elő, melynek telepítési feladatait előkészítettük. Az új telepítéssel további lehetőség nyílik a képzési és kutatási potenciál erősítésére, annak érdekében, hogy a kar meg tudjon felelni a gazdaság elvárásainak, az Ipar 4.0, a digitalizáció kihívásainak. A kar képzési programjában, a gépészmérnöki, a mechatronikai mérnöki szak tananyagában fontos szerepet kapnak a robotrendszerek, a robotizált gyártás, a robottechnikai alkalmazások. Az új hegesztőrobot és perifériái átvételével a robotállomás felügyeletét ellátó Anyag- és Gyártástudományi Intézet Anyagtechnológiai Intézeti Tanszék közreműködésünkkel megkezdte az előkészületeket a telepítési terv elkészítésére, a robotállomás kialakítására, a biztonságos üzemeltetési feltételek megteremtésére. Funkcióját tekintve a robotrendszer bemutató laboratóriumi célokra szolgál a gépészmérnöki, a mechatronikai mérnöki szakos, valamint a nemzetközi hegesztőmérnök és hegesztőtechnológus hallgatók részére, emellett ellát kutatási feladatokat, eszközrendszerével bekapcsolódik a TDK-, valamit a diplomafeladatok kutatási feladataiba. Ezen túlmenően a CLOOS magyarországi képviselete oktatásokat is szervezne a partnerek, alkalmazottak és a Kar hallgatói számára. A helyiség a kar „A” épületrészéből nyílik, nagy belmagasságú, mindkét ablaka az udvarra néz. A padlózata a munkavégzéshez megfelelő, elegendő fény biztosított az ergonomikus munkavégzéshez. A CROWN International Kft. az alábbi berendezéseket biztosította az új robotállomás kialakításához:

- QRC-290 robotkar;

- Quineo NexT 452 DC áramforrás;

- QC9 Basic Quriox Controller;

- WP-TS forgatható és billenthető manipulátor.

A berendezések átvételét követően az 2. fejezetben leírt szabályozások és szempontok figyelembevételével történt a telepítés előkészítése és megvalósítása.
A robot elhelyezése során figyelembe kellett vennünk munkaterületét, valamint azt is, hogy 360 fokban képes a mozgásra. A hely mérete és adottságai miatt a falhoz közel kellett telepíteni, így mindenképpen indokolttá vált a robot munkaterének szoftveres lehatárolása. A laboratórium bemutató funkciója miatt is kiemelten fontos szempont volt a robot megfelelő elhatárolása. Praktikussági okokból egy rácsos elkerítés tolókapuval kerül kialakításra. Az elkerítés tervezése során az alábbi kritériumokat határoztuk meg a rendelkezésre álló szűk terület miatt

- a tolókaput úgy kell megtervezni, hogy mindkét szárnya betolható legyen a 600 mm méretű falelem mögé, mellyel az anyagvastagságot és az ütközők méretét leszámítva 1100-1200 mm-es nyílás biztosítható legyen;

- a vezérlőszekrénynél sarkos letörés kialakítása a vezérlőszekrény tetejére, melynek mérete 1350 mm magasságú (a keret magasságával egyező) és 1000 mm szélességű legyen.

$\mathrm{Az}$ ívfény elleni védelem kialakítása során lehetőség lett volna a teli falú kerítésnél és a tolókapuknál munkaablak elhelyezésére, de a mun-

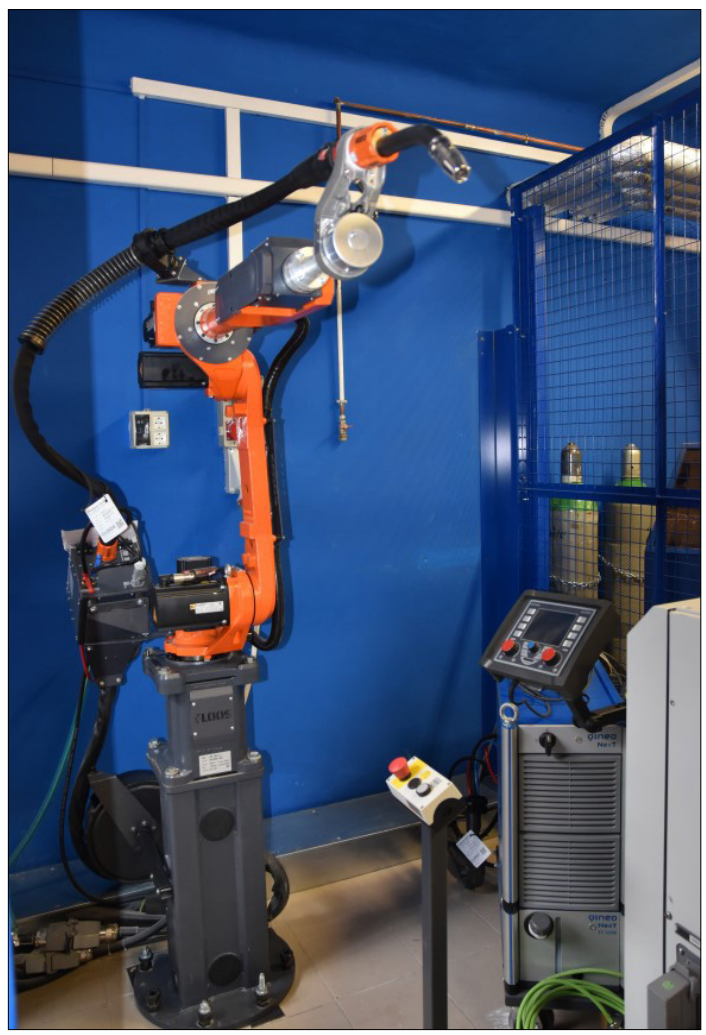

1. ábra. A telepített robotrendszer részlete a hegesztőrobottal, az áramforrással 
kafolyamat alatti jobb megfigyelési lehetőség biztosítása érdekében a rácsos kivitel mellett döntöttünk. A megfelelő védelmet automatikus sötétedésű fejpajzs alkalmazásával biztosítjuk.

A laboratórium egyidejűleg egyedi kísérleti vagy kiscsoportos foglalkozások lebonyolítására alkalmas. Az ívfény elleni védelem biztosítása érdekében szükségessé vált az udvarra nyíló, földszinti helyiség ablakai megfelelő fokozatú sötétítőfóliával történő bevonása is. A keletkező hegesztési füstök elszívásához a már korábban beszerzett KEMPER, $1700 \mathrm{~m}^{3} / \mathrm{h}$ teljesítményü légelszívó berendezés áll rendelkezésre állt, melynek használata előtt felvettük a kapcsolatot a gyártó céggel, kérve a berendezés hitelesítését, valamint a készülék üzembe helyezését.

A falra szerelhető, szívóernyős berendezés biztosítja a nemkívánatos gázok, gőzök és a szálló elemi részecskék eltávolítását és szűrését. A robotrendszer használata szabályozott, jogosultsághoz kötött, így biztosítható, hogy illetéktelen személyek ne juthassak be a laboratórium területére, a berendezéseket ne üzemeltethessék.

\section{5. Összefoglalás}

Dolgozatunkban egy robotrendszer telepítésének jogi szabályozását, európai és hazai jogszabályrendszerének bemutatását követően áttekintettük a hegesztőrobotok üzemi telepítésének számos kritériumát, a biztonsági szabályozás lehetőségét. Az áttekintett feltételek alkalmazását az Óbudai Egyetem Bánki Donát Gépész és Biztonságtechnikai Karának Cloos Robothegesztő Laboratóriumára vonatkoztatva ismertettük. A tevékenység további célja az üzembe helyezési eljárást követően egy szabályozás létrehozása, mely összegzi a biztonságos munkavégzés kritériumait, valamint a teendőket vészhelyzet esetén.

\section{Szakirodalmi hivatkozások}

[1] International Federation of Robotics Statistical Department: World Robotics 2011 Industrial Robots. ISBN 978-3-8163-0615-3. 13.

[2] Az Európai Parlament és a Tanács 2006/42/EK irányelve a gépekről és a 95/16/EK irányelv módosításáról. Az Európai Unió Hivatalos Lapja 2006. 06. 09.

[3] 143/2004. (XII. 22.) GKM rendelet a Hegesztési Biztonsági Szabályzat kiadásáról. Melléklet. 4. oldal 5.2.1.

[4] Hegesztési zsebkönyv. (szerk.: Gáti J.) Cokom Mérnökiroda Kft., Miskolc, 2003.

[5] Farkas A.: Hegesztőrobot-rendszerek biztonságtechnikája. 25. Jubileumi Hegesztési Konferencia, Budapest, 2010. május 19-21.

[6] Barabás P., Farkas A., Kérdy Á., Uzonyi S.: Hegesztőrobotok alkalmazási határainak kibővitése korszerü módszerekkel. XXX. Jubileumi Nemzetközi Hegesztési Konferencia, 2021. január 28-30.

[7] 1993. évi XCIII. törvény a munkavédelemről. 